\title{
Author Correction: Membrane protein megahertz crystallography at the European XFEL
}

Chris Gisriel (1), Jesse Coe, Romain Letrun (1), Oleksandr M. Yefanov, Cesar Luna-Chavez (1), Natasha E. Stander, Stella Lisova, Valerio Mariani, Manuela Kuhn, Steve Aplin, Thomas D. Grant (1), Katerina Dörner, Tokushi Sato, Austin Echelmeier (1), Jorvani Cruz Villarreal (10, Mark S. Hunter, Max O. Wiedorn, Juraj Knoska, Victoria Mazalova (D), Shatabdi Roy-Chowdhury, Jay-How Yang, Alex Jones, Richard Bean, Johan Bielecki, Yoonhee Kim, Grant Mills, Britta Weinhausen, Jose D. Meza, Nasser AI-Qudami, Saša Bajt@B, Gerrit Brehm, Sabine Botha, Djelloul Boukhelef, Sandor Brockhauser (D), Barry D. Bruce (D), Matthew A. Coleman, Cyril Danilevski, Erin Discianno, Zachary Dobson, Hans Fangohr (D), Jose M. Martin-Garcia, Yaroslav Gevorkov (D), Steffen Hauf, Ahmad Hosseinizadeh, Friederike Januschek, Gihan K. Ketawala, Christopher Kupitz, Luis Maia, Maurizio Manetti, Marc Messerschmidt, Thomas Michelat (D), Jyotirmoy Mondal (D), Abbas Ourmazd(D), Gianpietro Previtali, losifina Sarrou, Silvan Schön, Peter Schwander, Megan L. Shelby, Alessandro Silenzi, Jolanta Sztuk-Dambietz, Janusz Szuba, Monica Turcato (1), Thomas A. White (D), Krzysztof Wrona, Chen Xu, Mohamed H. Abdellatif, James D. Zook, John C.H. Spence, Henry N. Chapman (1), Anton Barty, Richard A. Kirian, Matthias Frank (D), Alexandra Ros, Marius Schmidt (D), Raimund Fromme (1D, Adrian P. Mancuso, Petra Fromme \& Nadia A. Zatsepin

Correction to: Nature Communications https://doi.org/10.1038/s41467-019-12955-3, published online 4 November 2019.

The original version of this Article contained errors in the email address of the corresponding author, Nadia A. Zatsepin, as well in her current affiliation. These have now been corrected in both the PDF and HTML versions of the article.

Published online: 30 January 2020

\footnotetext{
(c) (i) Open Access This article is licensed under a Creative Commons Attribution 4.0 International License, which permits use, sharing, adaptation, distribution and reproduction in any medium or format, as long as you give appropriate credit to the original author(s) and the source, provide a link to the Creative Commons license, and indicate if changes were made. The images or other third party material in this article are included in the article's Creative Commons license, unless indicated otherwise in a credit line to the material. If material is not included in the article's Creative Commons license and your intended use is not permitted by statutory regulation or exceeds the permitted use, you will need to obtain permission directly from the copyright holder. To view a copy of this license, visit http://creativecommons.org/licenses/by/4.0/.
}

(c) The Author(s) 2020 